\title{
GLOBAL DIVERSIFICATION OF GENERA DURING THE ORDOVICIAN RADIATIONS
}

SEPKOSKI, J. John, Jr., Department of the Geophysical Sciences, University of Chicago, Chicago, IL 60637, U.S.A.

The global diversity of marine animal genera more than tripled over the course of the Ordovician radiations. Data on these genera, resolved to the stratigraphic level of subseries, suggest that most of this diversification was quite rapid, confined to the middle third of the Period. Standing numbers of genera during the Tremadocian and early Arenigian remained at Cambrian levels; however, during this interval, genera of the Cambrian evolutionary fauna slowly dwindled while genera in the Paleozoic fauna increased in balance. The Ordovician radiations began in earnest in the late Arenigian with rapid expansion of genera in the Paleozoic fauna. The data then show an enigmatic halt in global diversification during the Llanvirnian, with some groups (notably brachiopods, cephalopods, and graptolites) exhibiting a decline in diversity into the late Llanvirnian. It is not clear, however, if this represents a second-order extinction event or simply inefficient sampling of the fossil record around the Sauk-Tippecanoe sequence boundary.

The data show diversification resuming in the Llandeilian and then decelerating after the early Caradocian upon reaching a level of about 1600 genera. All three evolutionary faunas contributed to this final surge: early members of the Modern fauna more than doubled in diversity to about 340 genera, and even some surviving components of the Cambrian fauna (including trilobites and lingulate brachiopods) rediversified by about 10 percent. These latter groups fared poorly, however, at the end-Ordovician mass extinction, which eliminated 60 percent of all animal genera and drove diversity back to levels of the late Arenigian. Interestingly, the Silurian rebound returned global genus numbers back to late Ordovician levels over about the same time span as the radiations of the late Arenigian to mid-Caradocian, if the Llanvirnian perturbation is ignored. 